\title{
Influence of gender on the prevalence of Rsi/ WRULD in meat-packing plants
}

\author{
Reis, P. ${ }^{\mathrm{a}, \mathrm{b}^{*}}$, Moro, A. ${ }^{\mathrm{a}, \mathrm{c}}$ Merino, Eugenio ${ }^{\mathrm{a}}$ Vilagra, J. ${ }^{\mathrm{d}}$ \\ a Programa de Pós-Graduação em Engenharia de Produção, Universidade Federal de Santa Catarina, SC, Brazil \\ ' Instituto de Ensino Superior de Foz do Iguaçu, Pr, Brazil \\ ${ }^{\mathrm{c}}$ Programa de Pós-Graduação em Educação Física, Universidade Federal de Santa Catarina, SC, Brazil \\ ${ }^{\mathrm{d}}$ Departamento de Fisioterapia, Universidade do Oeste do Paraná, PR, Brazil
}

\begin{abstract}
This research aimed to determine the handgrip strength difference between $(\delta)$ and $(+)$ and its influence on the incidence of RSI / WRULD in meat-packing plants. The study had the participation of 201 workers from the bone sector of a pig slaughterhouse located in the municipality of Sao Miguel do Iguacu, state of Parana, Brazil, being 98 men and 103 women with mean age of $34.3( \pm 4.7$ years) and weight of $66.3( \pm 6.5 \mathrm{~kg})$ for $(+$ ) $)$ and 36.5 ( \pm 6.4 years) and weight of $77.6( \pm 5.8 \mathrm{~kg})$ for $(\AA)$. Handgrip strength was used in the evaluation. Descriptive statistics and " $\mathrm{t}$ " test were applied, with significance level of $0.05 \%$ for strength test and percentage of pain levels. The results were presented according to gender $\left({ }^{\lambda}\right) 44.94 \mathrm{kgf}( \pm 4.51)$ for the dominant hand $(\mathrm{DH})$ and $41.09 \mathrm{kgf}( \pm 4.09)$ for the non-dominant hand $(\mathrm{NDH})$, and for males $(+9)$, the average was $29.20 \mathrm{kgf}( \pm 2.20)$ for $\mathrm{DH}$ and $28.40 \mathrm{kgf}( \pm 2.39)$ for NDH. Statistical analysis indicated a " $\mathrm{t}$ " greater than 0.05 with $3.49 \%$ for DH and 2.95 for $\mathrm{NDH}$, showing that $\left(\delta^{\lambda}\right)$ and $(9)$ have strength levels significantly different in both hands and this study indicated that females have 35\% less strength in the DH and 30.8\% in the NDH. With regard to pain symptoms, pain for (P) was higher than for $\left({ }^{\pi}\right)$, with $21.5 \%$ in the shoulder region, $25 \%$ in neck, $48 \%$ in the column, $48.7 \%$ and in the arms and $48.8 \%$ in wrists and hands. It could be concluded that $(q)$ have less strength and higher percentage of pain in relation to $\left(\delta^{\top}\right)$ when exposed to repetitive work and with identical tasks. Thus, it becomes clear that to avoid RSI / WRULD in meat-packing plants, companies should use knowledge on ergonomics in order to provide a work environment that respects the physiological differences between males and females.
\end{abstract}

Keywords: Ergonomic hazards; women; handgrip strength

\section{Introduction}

The worker's health has been significantly affected in the agribusiness sector, especially in meatpacking plants, which has grown dramatically, according to the current economic development of Brazil [2]. Under normal conditions, women () have $40 \%$ less strength in relation to men $(\circlearrowleft)$. In addition, approximately two to three days before menstruation, women show significantly altered hormonal rates, mainly due to decreased progesterone, increased aldosterone, estrogen and cortisol levels [27]. These hormonal changes cause various symptoms, highlighting fluid retention, irritability, stress and loss of strength [46]. This fact reinforces indicators of the Brazilian Institute of Social Security, which reported in its official data that the prevalence of Repetitive Strain Injuries (RSI) and Work-Related Upper Limb
Disorders (WRULD) is greater among women, especially when exposed to repetitive work [10]. RSI/ WRULD is already considered a major public health problem, and in companies, they are considered the most severe, affecting workers globally and especially in Brazil, causing high disability rates, in addition to the high costs of removals and treatments, either temporary or permanent [37]. In this sense, the isometric grip strength of hand finger plays an important role in the diagnosis of upper limb functionality, representing an important indicator of RSI/ WRULD [21]. Thus, the aim of this study was to verify the difference in grip strength between men and women and its influence on the incidence of RSI/ WRULD in meat-packing plants, whereas the prevalence among women is higher, and out of 10 workers who become ill from RSI/ WRULD, 7 are female () [10].

\footnotetext{
* Corresponding author: Pedro Ferreira Reis - Instituto de Ensino Superior de Foz do Iguaçu, Pr, Brazil - Universidade Federal de Santa Catarina, SC, Brazil - Programa de Pós Graduação em Engenharia de Produção - Ergonomia - Laboratório de Biomecânica - Campus Universitário Trindade, Florianópolis, SC, Brazil. CEP: 88040-970; Tel. (55) 4837218530; E-mail: ergoreis@hotmail.com
} 
In contemporary Brazil, meat processing industries have provided a considerable development in the Brazilian economy. Increasing levels of exports clearly indicate this fact, resulting in a large job creation in this sector [11]. However, improvements in the ergonomics in the workplace of this sector have not grown at the same rates. The rhythm imposed by the production line at slaughterhouses prevents the worker to have his own regulation, and its pace is established by the machine, irrespective of the need for turnovers and recovery breaks. Thus, it is important to warn companies with repetitive tasks that no worker should be exposed for more than 60 minutes without pause for recovery, indicating a ratio of $5: 1$, i.e., the worker should have 10 minutes out for recovery at every 60 minutes of work, so that the worker is not prone to diseases [15].

The Brazilian rules governing the labor conditions, which act in both prevention and treatment, have undergone changes, and the term RSI (repeated strain injury) has been currently used when the disease is already established, while the term WRULD (Work-Related Upper Limb Disorders) is used for symptoms such as paresthesia, pain, formication or discomfort. Thus, academicians and professional both use the term RSI / WRULD [51].

The nomenclature RSI lasted until late 1990s, when the Technical Standard No. 606/98 of the National Institute of Social Security proposed the designation of WRULD, which was defined as a syndrome characterized by chronic pain, which manifested primarily in the upper limbs, affecting tendons, muscles and peripheral nerves [10]. However, even with all the ergonomic and epidemiological evidence, there remains a difficulty in connection with the work in 2003, in which another revision of the instruction was performed, which grouped the two nomenclatures, becoming RSI / WRULD [11].

For purposes of labor rights and social security benefits, RSI / WRULD follow the same rules of a work accident [10]. Therefore, Social Security data indicate that currently, RSI / WRULD are responsible for more than $80 \%$ of occupational diseases, resulting in a large number of removals [40].

A result from an imbalance between the worker's physical capacity and the work demands, RSI / WRULD is classified into 04 levels, which go from spontaneous pain that does not interfere with productivity to unbearable pain with loss of labor functions [13,35, 42]. In general, workers with RSI / WRULD present discomfort such as diffuse and localized pain, feeling of heaviness, fatigue, numbness, tingling, decreased handgrip strength, muscle stiffness, sweating and shocks, among others, resulting in a significant number of removals, humiliations, suffering and high costs of labor indemnifies $[14,17,19,34,50]$.

RSI / WRULD are already considered a major public health problem, and in companies, they are considered the most severe, affecting workers globally and especially in Brazil, causing high rates of labor disabilities, in addition to the high costs of absenteeism and treatments, whether temporary or permanent $[11,37]$. In Brazil, this problem is not new, because in 2001, the Ministry of Health in its indicators, reported that $6 \%$ of the Brazilian labor force were affected by RSI / WRULD, with a monthly expenditure of one billion with diseases and work accidents [53].

Although in Brazil the Technical Standard to assess labor disabilities established by the Ministry of Social Security proposes stages for the evolution of Repetitive Strain Injury (RSI) and Work-Related Upper Limb Disorders (WRULD) $[6,11,21,51]$, it is observed that surveys are limited to show the occurrence of injuries, highlighting the risk to the worker, but it is very important to establish the degree to which the worker is affected, so that the intervention is effective. Thus, the change of function or removal will contribute to a healthy recovery, because an ergonomic intervention focused only on the work organization will not contribute to the health of workers who are already affected by RSI / WRULD [18].

RSI / WRULD may have a strong relationship not only with physical factors, but also with psychosocial factors, highlighting the repetition of movements, incorrect posture, use of physical force and the search for productivity without limits, highlighting RSI / WRULD of the upper limbs [23]. Psychosocial problems are considered a risk factor for RSI / WRULD, where the accelerated pace both for work activities and for physiological needs, added to low wages, provide high levels of work dissatisfaction [8].

The continuous advance of RSI / WRULD worldwide results in economic and social problems coming from the loss of labor function, generating high costs for organizations and government [52]. Multidisciplinary teams have over time researched about occupational diseases, originating numerous discussions in the health sector, mainly in the medical field, because the diagnosis is difficult and complex. The diagnosis of RSI / WRULD is based on pain symptoms, which may not present a real data, 
since the pain perceived by the individual may not be related to his functional capacity [53]. These authors reported that within organizations, it is important to use tools that can provide more reliable data, since the fear of losing one's job can contribute to the omission of important facts at the time of diagnosis of RSI / WRULD.

Currently, significant changes in the labor market have been observed, coming from a social and economic transformation, mainly by the presence of women. External factors combined with stress from work will contribute to the occurrence of diseases, since these factors will hinder adaptations and adjustments of the worker [27]. In this context, it appears that the stressing agents can have occupational and social origin, in which domestic factors that may interfere in their regulation must also be considered, especially in case of female workers [5]. Women, especially married ones perform double duty, which are divided between the work hours, domestic service and dedication to children and husband [38,39]. In this sense, the author warns that due to their double duty, women have reduced time for rest and leisure, remaining vulnerable to diseases because they need to make a greater effort than males due to their 30\% lower physiological strength level [27].

Repetitive work provides significant contractions in the joints of upper limbs, mainly wrist and hand, where diseases such as carpal tunnel syndrome, Ghion channel syndrome and Quervain syndrome show higher prevalence in women, with an incidence of $7 \times 1$ in relation to men [31,30]. Contemporary data show that in the diagnosis of RSI / WRULD, women have a significantly greater percentage than men, reporting that at every ten workers with symptoms of RSI / WRULD, seven are women [10].

hormonal rate is significantly changed, mainly due to the drop of progesterone, increase of aldosterone, estrogen and cortisol from the premenstrual syndrome, with prevalence from 30 to $40 \%$ of women, leading to various symptoms, among them fluid retention, irritability, stress and loss of productivity [27]. Females have a unique feature called the menstrual cycle, which is divided into five distinct phases:

1. Menstrual phase: from $1^{\text {st }}$ to $3^{\text {rd }}$ day;

2. Post - Menstrual phase: from $4^{\text {th }}$ to $12^{\text {th }}$ day;

3. Ovulation phase: from $13^{\text {th }}$ to $14^{\text {th }}$ day;

4. Post - ovulation phase: from $15^{\text {th }}$ to $25^{\text {th }}$ day;

5. Pre - Menstrual phase: from $26^{\text {th }}$ to $28^{\text {th }}$ day [30-31].
The premenstrual phase shows a significant increase in the hormone cortisol and a significant drop in hormones progesterone and estrogen, starting the menstrual phase [26]. Thus, during this new phase, the progesterone and estrogen levels rise again, starting the new menstrual cycle, which will be present during the entire reproductive phase [16]. This author studied the women's productivity during the menstrual cycle, studying their hormonal changes and physical fitness, and found that ovule development and blood release occur in the menstrual phase, and at this phase, there are several emotional symptoms that affect them such as impatience, irritability, feeling like crying, mood instability, grief, anguish, anxiety, concentration difficulty and depression.

Pre-menstruation and menstruation symptoms occur due to the low concentrations of hormones estrogen and progesterone is increased levels of cortisol, providing a significant decrease in strength, resistance and velocity. In phase after menstruation, there is an increase in the progesterone and estrogen levels, also increasing velocity and resistance. This author also reported that although these two hormones are always together during increase and reduction, this no longer occurs in the ovulation phase because at this stage, progesterone increases in detriment of estrogen, with decreased strength and motor coordination [28,32]. In the post menstrual phase, progesterone is released in large amounts, providing a significant gain in strength, velocity and resistance, unlike the pre-menstrual phase that, due to the non-fertilization, there is an emotional disorder, with significant drop of hormones, significantly affecting performance and therefore productivity [16]. At this stage, there is a significant reduction of force, resistance and concentration, due to the loss of immunity, impairing the recovery capacity and therefore leading to higher tendency to fatigue, leaving an open path to the occurrence of diseases $[24,44,55]$.

A study conducted with 15 female workers exposed to repetitive work found a significant increase of stress and cortisol levels during the premenstrual and menstrual phases, and the majority of surveyed women reported symptoms such as irritation, desire to miss work, memory loss and mood changes [44].

Injuries arising from repetitive movements, called RSI / WRULD, affect the muscular system, where joints, ligaments, tendons and nerves are the most affected, mainly when the worker does not make recovery breaks, thus contributing to the evolution of 
the oxidative stress $[15,45]$. This situation will trigger pathologies, with loss of productivity, which will be aggravated if the individual is at high rates of stress hormone, and cortisol is the hormone most involved in this situation $[27,29,48]$. Preventing the advancement of any pathology will contribute to a better quality of life of workers, and an important method to help preventing this condition is the ergonomic analysis of work, which can detect and indicate ways to solve the problem $[15,25,36,45]$.

\section{Method}

\subsection{Participants}

This is a cross-sectional cohort study conducted with the participation of 201 subjects, 103 women $(P)$ and 98 men $(\delta)$ aged 25 to $40 \pm 5.02$ years, mean age of 34.3 ( \pm 4.7 years) and weight of $66.3( \pm 6.5$ $\mathrm{kg}$ ) for ( $(+)$ and 36.5 ( \pm 6.4 years) and weight of 77.6 $( \pm 5.8 \mathrm{~kg})$ for $\left(ठ^{\varkappa}\right)$, who work in a pork-packing plant located in the municipality of São Miguel do Iguacu, Parana, Brazil. The procedures were approved by the local Committee for Ethics in Research with Human Subjects, according to the Declaration of Helsinki.

\subsection{Instruments}

Through the Jamar ${ }^{\circledR}$ hand dynamometer, used to measure the handgrip strength in $\mathrm{kg} /$ strength (kgf). The protocol used for carrying out handgrip strength assessments was the same adopted and recommended by the Brazilian Society of Hand and Upper Limb Therapists. Where the employee performs the test in the sitting position with spine and thighs supported on the chair, knees flexed $90^{\circ}$ and both feet on the ground [1]. Joint pain was determined using the body map for evaluating discomfort in which workers reported the pain perceived at the end of the working hours [18].

\subsection{Data Analysis}

The test was conducted with all participants in both hands (right and left). The data were processed through descriptive statistical analysis and t-test, using the SPSS 14.0 software for Windows, adopting a significance level of $0.05 \%$ [7].

\section{Results}

The results showed for males (ठ) $44.94 \mathrm{kgf}( \pm$ 4.51) for the dominant hand (DH) and $41.09 \mathrm{kgf}( \pm$ 4.09) for the non-dominant hand (NDH), while for females, the average was $(+)$ 29.20 $\mathrm{kgf}( \pm 2.20)$ for $\mathrm{DH}$ and $28.40 \mathrm{kgf}( \pm 2.39)$ for NDH (Table 1).

Table 1

Handgrip Strength Levels between Men and Women

\begin{tabular}{|c|c|c|}
\hline Hand & $\left({ }^{\wedge}\right)$ & $(+)$ \\
\hline $\mathrm{DH}$ & $44.94 \mathrm{kgf}( \pm 4.51)$ & $29.20 \mathrm{kgf}( \pm 2.20)$ \\
\hline $\mathrm{NDH}$ & $41.09 \mathrm{kgf}( \pm 4.09)$ & $28.40 \mathrm{kgf}( \pm 2.39)$ \\
\hline
\end{tabular}

Statistical analysis indicated in the " $\mathrm{t}$ " distribution table with $(201-2=199)$ the degree of freedom and significance level adopted in $0.05 \%$, the critical value is 1.65 , with a " $t$ " value established in this study greater than $0.05 \%$ with 3.49 in $\mathrm{DH}$ and 2.95 in $\mathrm{NDH}$, confirming that $(\hat{\sigma})$ and () have significantly different strength values in both hands, and the present study indicated that (O) have 35\% less strength in the $\mathrm{DH}$ and $30.8 \%$ less strength in the $\mathrm{NDH}$.

Figure 1 reports the bodily discomfort by the end of work shift, indicating a higher percentage for women.

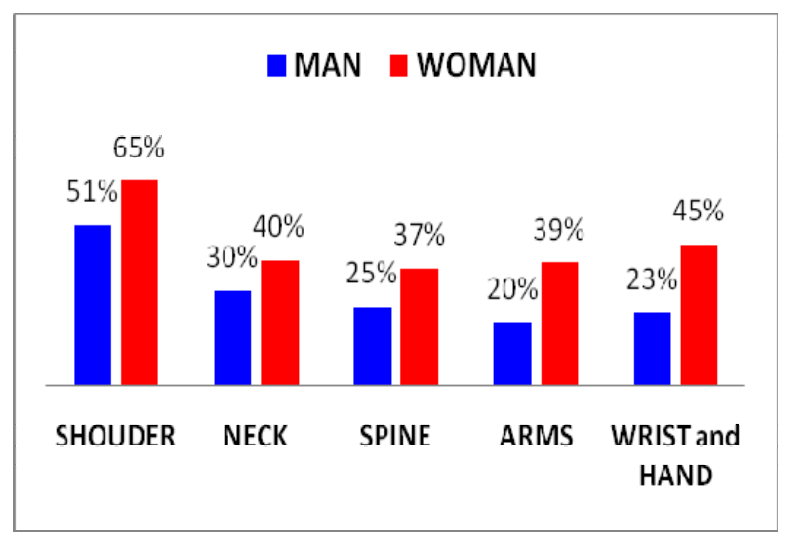

Fig. 1 - Discomfort percentage between Men and Women

The discomfort percentage in shoulders was 51\% for $(\widehat{\partial})$ and $65 \%$ for $(+9)$, neck was $30 \%$ for $(\lesssim)$ and $40 \%$ for ( $(+)$ ),column was $25 \%$ for $(\circlearrowleft)$ and $37 \%$ for $(Q)$, arm was $20 \%$ for $(\circlearrowleft)$ and $39 \%$ for $(+)$ and wrist and hand was $23 \%$ for ( $\overbrace{}^{\star}$ ) and $45 \%$ for (). The pain symptoms were higher for $(+)$ than for $(\lesssim)$ with 
$21.5 \%$ in the shoulder region, $25 \%$ in neck, $48 \%$ in column, $48.7 \%$ in arms and $48.8 \%$ in wrists and hands. Is was concluded that $(+$ ) have less force and higher pain percentage in relation to $(\lesssim)$ when exposed to repetitive work with identical tasks (Figure1).

\section{Discussion}

It is public knowledge that Repetitive Strain Injuries (RSI) arise in subjects exposed to continuous and repetitive activities, with pain complaints, which mainly affect the upper limbs (UL) [45].

Today, it is observed that the globalized world provides a search for productivity at low cost and an ever accelerating pace of the tasks performed by workers, significantly contributing to the increased inclusion of women on work fronts. Thus, it is necessary to understand that their physiology is different from that of men, both in reproductive issues, strength level and respiratory capacity [27].

This insertion still does not include equality in physical, physiological and psychological conditions between men and women. It is public knowledge that women have $40 \%$ less force and $30 \%$ less cardio respiratory capacity in relation to men. In addition to these individual differences, the physiological issue plays an important role that should be considered in the execution of the work by women, especially when the task is repetitive, not considering tasks culturally performed by women, including domestic and family activities. In this sense, when exposed to repetitive tasks, women will be significantly more prone to the occurrence of labor diseases, because the swelling in joints affects the entire musculoskeletal system [27,29,44, 45].

In today's labor market, men and women usually perform tasks, which are governed by a single work organization, not respecting the biological individuality. Women have hormonal release, which contributes to the emergence of stress and fluid retention due to their natural reproduction cycle. When they are exposed to repetitive movements, there is a significant prevalence of diseases due to fluid retention and low immunity. In this sense, understanding the female physiology becomes of great importance to ergonomics, so that companies can offer women a comfortable and safe working environment [27,29,44,45].

Old surveys have already reported that during the menstrual cycle, especially during the pre-menstrual phase, women have several symptoms that contribute to the occurrence of diseases, among them the swelling from hormonal alterations, reaching a significant percentage of women, over 92\% [4]. In this sense, when exposed to repetitive work, women are significantly more prone to the occurrence of diseases, because the swelling in joints affects the entire musculoskeletal system [29]. Current data from the Brazilian Institute of Social Security on the number of sickness benefits from musculoskeletal and connective tissue disorders, which comprise various diseases, also show a higher percentage for women [3].

It is public knowledge that the incidence of diseases from repetitive tasks is proportionally larger in women, showing a very high percentage, indicating that at every ten workers with symptoms of RSI / WRULD, seven are women [10]. The double duty performed by women, the use of contraceptives, menstrual cycle and reduced respiratory and muscular capacity provide them worse conditions in relation to men when exposed to the same work organization $[22,44]$.

In a study conducted in poultry slaughterhouses measuring the handgrip strength, it was found that the men's strength level is $10 \mathrm{kgf}$ higher than that of women [20]. In this sense, it could be inferred that when exposed to the same type of repetitive task with handgrip strength requirements, women have a much higher prevalence of illness in relation to men. Current studies have shown that the musculoskeletal injuries reported by workers who work in computer environments is significantly higher among females, especially in the column, wrists, hands and shoulder joint $[9,41]$.

In the world of work, it is important to understand individual differences and mainly the heterogeneity of physiology in relation to gender. Thus, it could be observed that several surveys have reported a much higher prevalence in women $[33,49]$. Comparing females with males, the percentage of pain symptoms was significantly greater in women in relation to men $[12,46,43]$. The Brazilian Institute of Social Security reports higher RSI / WRULD indexes in females, especially when exposed to repetitive work [10]. In this sense, changing the guidelines of work organizations by analyzing the relationship of women with work becomes an important tool during the ergonomic analysis of work [45]. Thus, these measures will contribute to a more humanized work environment for this population, since most of them, in addition to working in the company, have domestic works such as attention to children and 
husband and household activities [27,44]. Therefore, it is important to observe that ergonomics plays an important role in adjusting the work to the psychophysiological characteristics of the being human in the work environment. It is important to consider the physiological differences between sexes, so that the work environment is more humanized, comfortable and safe $[25,27,44,45]$.

It was concluded that $(\hat{O})$ and $(+)$ have significantly different grip strength levels in both hands. Therefore, it is important to emphasize that in repetitive tasks and using strength, one cannot expect the development of tasks with the same work organization for $(\circlearrowleft)$ and (ㅇ). In this sense, ergonomics will avoid RSI/ WRULD in meat-packing plants and provide a work environment respecting physiological differences between $(\circlearrowleft)$ and $(\phi)$.

\section{Acknowledgements}

This study was supported by the food company FRIELLA.

\section{Reference}

[1] L.M. Abdalla and M.C.F. Brandão, Força de preensão palmar e digital. In: Sociedade Brasileira de Terapeutas da Mão e do Membro Superior. Manual: recomendações para avaliação do membro superior. $2^{\mathrm{a}}$ ed. São Paulo, editora SBTM, 2005.

[2] ABEF, Associação Brasileira dos Produtores e Exportadores de Frangos (2010), Relatório anual 0910, Retrieved from: http://www.abef.com.br/portal/_clientes/abef/cat/RA_2010.pd f.

[3] AEPS, Anuário Estatístico da Previdência Social/Ministério da Previdência Social, Empresa de Tecnologia e Informações da Previdência Social - Brasília: MPS/DATAPREV, 2008, pp 427, Retrieved from: http://www.previdencia.gov.br.

[4] B.Andersch, et al., Premenstrual complaints: Prevalence of premenstrual symptoms in a Swedish urban population. J. Psychosom. Obstet. Gynaecol. 5(1986),39-46.

[5] R.Antunes and G.Alves, Changes in the world of work in the globalization of capital era, Campinas, Educação e Sociedade 87(2004), 335-351.

[6] L.G.Barbosa, Fisioterapia Preventiva nos Distúrbios Osteomusculares Relacionados ao Trabalho - DORT's. Rio de Janeiro, $2^{\mathrm{a}}$ edição, editora Guanabara Koogan, 2008, pp.224.

[7] M.V.G. Barros and R.S.Reis, Análise de dados em atividade física e saúde: demonstrando a utilização do SPSS. $1^{\mathrm{a}}$ ed. Londrina:, editora Midiograf, 2003, pp.216.

[8] P.M.Bongers, et al., Are psychosocial factors, risk factors for symptoms and signs of the shoulder, elbow, or hand/wrist? A review of the epidemiological literature, Am J. Ind. Med. 41(2002), 315-342.

[9] A.G.Brandão, et al., Signs of musculoskeletal disorders in bank workers from the city of Pelotas and region: prevalence and associated factors, Rev. Brás. Epidemiolog. 8(2005), 295 305.

[10]Brasil, Ministério da Saúde. Lesões por esforços repetitivos (LER)/Distúrbios osteomusculares relacionados ao trabalho (DORT). Brasília: Ministério da Saúde, 2001, Retrieved from: http://bvsms.saude.gov.br/bvs/publicacoes/ler_dort.pdf.

[11]Brasil, Ministério da Saúde. Instrução normativa INSS/DC n ${ }^{\circ}$ 98, de 05 de dezembro de 2003, Aprova Norma Técnica sobre Lesões por Esforços Repetitivos LER ou Distúrbios Osteomusculares Relacionados ao Trabalho DORT, Brasília: Ministério da Saúde; 2003b, Retrieved from: http://www81.dataprev.gov.br/sislex/imagens/paginas/38/inss dc/2003/anexos/INDC98ANEXO.htm.

[12] P.M.S.Carneiro, Análise ergonômica da postura e dos movimentos na profissão de médico dentista, Dissertação Msc. Escola de Engenharia da Universidade do Minho, 2005, pp. 120 .

[13]M.P. Carvalho, C.C.D. Lanna and M.B. Bértolo, Reumatologia Diagnóstico e Tratamento. $3^{\mathrm{a}}$ Edição, editora Guanabara Koogan, 2008, pp. 223-231.

[14]L.G.Chiavegato and A. Jr. Pereira, Work related osteomuscular diseases: multifactorial etiology and explanatory models, Interface - Comunic. Saúde, Educ. 14(2003), 149-162.

[15]D. Colombini, Método Ocra para a análise do risco por movimentos repetitivos: Manual para avaliação e a gestão de riscos, Editora LTR. São Paulo, 2008, pp.333.

[16] N.W. Constantini, et al., The menstrual cycle and sport performance. Clinica de Sports Med., Philadelphia 24(2005),5182.

[17] H.J.Coury, Time trends in ergonomic intervention research for improved musculoskeletal health and comfort in Latin America Appl. Ergon. 36(2005), 249-252.

[18]A.H.Couto, Como gerenciar a questão das LER./DORT: Lesões por Esforços Repetitivos / Distúrbios Osteomusculares Relacionados ao Trabalho, $1^{\circ}$ Edição Ergo editora, Belo Horizonte, MG, 1998, pp.433.

[19] G.C.David, Ergonomic methods for assessing exposure to risk factors for workrelated musculoskeletal disorders. Occup. Med. 55(2005), 190-199.

[20]J.C. Defani, Avaliação do perfil antropométrico e análise dinamométrica dos trabalhadores da agroindústria do setor de frigoríficos e abatedouros: o caso da Perdigão - Carambeí, Dissertação de Mestrado, Programa de Pós Graduação em Engenharia de Produção, Universidade Tecnológica Federal do Paraná, Ponta Grossa, 2007.

[21]X. Dennett and H.J.H.Fry, Overuse syndrome: a muscle biopsy study, Lancet 1(1988), 905-908.

[22]D.S.Durante and E.M.Villela, Análise da Prevalência de Lesões por Esforço Repetitivo nos Cirurgiões Dentistas de Juiz de Fora (MG), Revista do CROMG 7(2001),21-25.

[23]R.C.P.Fernandes, et al., Musculoskeletal disorders among workers in plastic manufacturing plants., Rev. bras. epidemiol, 13(2010), 11-20.

[24]A.C.Gomes, Treinamento desportivo: estruturação e periodização, Porto Alegre, editora Artmed, 2002, pp.276.

[25]F. Guérin, et al., Compreender o trabalho para transformálo: a prática da ergonomia, São Paulo, Editora Edgard Blucher.São Paulo, SP, 2001, pp.200.

[26]A. Guyton, Fisiologia Humana e Mecanismo das Doenças. $9^{a}$ ed. Rio de Janeiro, editora Guanabara e Koogan, pp.1998.

[27]I. Iida, Ergonomia: projeto e produção, $2^{a}$ ed. rev. e ampl. São Paulo: Edgard Blücher, 2005, pp.614.

[28]X.A.J.Jonge, Effects of the menstrual cycle on exercise performance, Sports Med., Auckland 33(2003), 833-851, 2003. 
[29]K.H.Kroemer and E.Grandjean, Manual de ergonomia: adaptando o trabalho ao homem, $5^{\text {a }}$ ed. Porto Alegre: Bookman, 2005, pp.338.

[30]O. Lech, M.G. Hoefel, Protocolo de Investigação das lesões por esforços repetitivos (LER). São Paulo, editora Rhodia Farma, 1994, pp.64.

[31]D.W. Levine, et al., A self administered questionnaire for the assessment of severity symptoms and functional status in carpal tunnel syndrome, Journal of Bone and Joint Surgery 75A(1993), 1585-1592.

[32] V. Linnamo, et al., Acute Hormonal Responses to Submaximal and Maximal Heavy Resistance and Explosive Exercixes in Men and Women. J. Strength Cond. Res. 19(2005), 566-571.

[33]A.C.C. Maciel, M.B. Fernandes and L.S. Medeiros, Prevalence and factors associated with pain symptoms in professionals of the textile industry, Rev. Bras. Epidemiolog. 9(2006), 94-102.

[34] T.S.B.S.Magnago, et al., Musculoskeletal disorders in nursing workers: evidences associated to work conditions, Rev. Bras. Enferm. 60(2007),701-705.

[35] A.R.C. Merlo, M.G.C. Jacques and M. G. L. Hoefel, Groups Activity with Repetitive Strain Injuries Workers: Experience Report, Psicol. Reflex. Crít. 14(2001), 253-258.

[36] Musse, C. A. Prevenção: A única saída da doença tenossinovite. Revista Proteção 6 (1989),42-57.

[37]N.T.Murofuse and M.H.P. Marziale, Diseases of the osteomuscular system in nursing workers, Rev. Latinoam Enferm. 13(2005), 264-273.

[38] C.M. Nogueira, A feminização no mundo do trabalho: entre a emancipação e a precarização, Editora Autores Associados, São Paulo, Brasil, 2004, pp.128

[39]C.M.Nogueira, O trabalho duplicado: a divisão sexual no trabalho e na reprodução: um estudo das trabalhadoras do telemarketing, Revista Brasileira de Saúde Ocupacional 114(2006), 173-175.

[40] M.J. O'neill, LER/DORT, O Desafio de Vencer. Madras Editora Ltda, 2003, pp.121.

[41]F.A.Pinheiro, B.T. Troccoli, B. And M.G.T. Paz, Psychosocial Predictors of Musculoskeletal Symptoms: The Relevance of Mediated and Moderated Relationships, Rev. Psicol. Reflex. Crit. 19(2006), 142-150.

[42]A. Puriene et al., Selfreported occupational health issues among Lithuanian dentists, Ind Health 45(2008), 369-374.

[43] G.I.Regis Filho, G. Michels and I. Sell, Work related musculoskeletal disorders in dentists, Rev.bras. epidemiol. 9(2006), 346-359.

[44]P.F. Reis, A.R.P. Moro and C.M.A. Reis, The mentrual cycle have influence on illnesses of female workers? A hormonal and symptomatologic approach, ABERGO, Rio de Janeiro, 1(2010), 1-7.

[45]P.F.Reis, A.R.P.Moro and L. Gontijo, The importance of ergonomics in aid of occupational diseases in workers with repetitive cycles, The FIEP Bulletin 74(2004), 50-62.

[46]D.W.Rising, B.C. Bennett, K. Hursh and O. Plesh, Reports of body pain in a dental student population, J Am Dent Assoc. 136(2005), 81-86

[47]F.C.B. Rodini, et al., Disability prevention in leprosy using a self-care manual for patients, Fisioterapia e Pesquisa, São Paulo 17(2010), 157-166.

[48] M.M. Rogero, et al., Plasma and tissue glutamine response to acute and chronic supplementation with L-glutamine and Lalanyl-L-glutamine in rats, Nutr. Res. 24(2004), 261-270.

[49] C.A. Salim, Doenças do trabalho: exclusão, segregação e relações de gênero, São Paulo Perspect. 17(2003), 11-24.

[50]L.U.Signori, L.B.M.Guimarães and R.M.F. Sampedro, Análise dos instrumentos utilizados para a avaliação do risco da ocorrência dos D.O.R.T./L.E.R., Produto \& Produção 7(2004), 51-62.

[51] J.R.Veronesi Junior, Perícia Judicial para Fisioterapêutas. São Paulo, editora Andreoli, 2009, pp.317.

[52]M.A.R.Verthein and C.M.Gomez, The trap: the discursive bases of the neuropsychiatrization in RSI. Ciência e Saúde Coletiva 6(2001), 457-470.

[53]I.A.P.Walsh, et al., Work ability of subjects with chronic musculoskeletal disorders, Rev. Saúde Pública 38(2004),149156.

[54]J. Weineck, Mulher e o esporte, In: Biologia do Esporte. São Paulo: Manole,1991, pp.353-375.

[55] J. Weineck, Biologia do Esporte, $7^{\mathrm{a}}$ ed. São Paulo, editora Manole, 2005, pp.758. 